\title{
Kádár, Judit. 2018. Az Új Idők az első világháború alatt (1914-1918) ['The New Times During World War I (1914-1914)']. Budapest: Országos Széchényi Könyvtár. 320 pp. Illus.
}

\author{
Reviewed by Maya J. Lo Bello ${ }^{1}$, ELTE BTK/TÓK
}

As rumors run rife in the Hungarian press and social media, even the most docile bibliophile cannot help but wonder whether the summer of 2019 will go down in history as that oppressively humid, quixotic season of flash floods, sudden cold fronts and merciless heatwaves; or will this instead be the summer when the National Library (OSZK) was ousted from Budapest's Castle district, its priceless collections scattered about the city? Or has OSZK only been closed because its building is actually being freed of asbestos and modernized to meet twenty-first century standards of digitalization? Although OSZK's fate in the academic wars currently taking place in Hungary is anyone's guess at this point, this institution's researchers and librarians continue to edit and publish select volumes that reflect OSZK's premier role in supporting the field of library science while continuously maintaining a connection with Hungarian-language collections located both within Hungary and abroad. Even though many of the volumes published by OSZK are geared toward the limited audience of academics, Judit Kádár's compilation of the articles, photos and novels published in the weekly paper Új Idök ['New Times'] between 1914 and 1918 amply demonstrates how philology's dusty archaeological process can be combined with periodical studies to reveal a narrative that proves just as readable and interesting to the layman as it does to the academic researcher.

One reason for arguing the applicability of Kádár's The New Times ['Új Idők'] During World War I lies in its eminent suitability as a handbook. The first impression I had of the volume surrounded the practical convenience with which a vast amount of staggeringly eclectic information is arranged not only in chronological order but also based on topic and subject. While its weight and roughly $11.5 " \mathrm{x} 8$ " size precludes this volume from easy transportation, the large pages reveal a format that enables the quick location and absorption of information, a convenience that is rarely found outside of a few textbooks in Hungary. For me, as someone who tends to read the footnotes and bibliography first, Kádár's work has opened my eyes to the pleasure of marginalia: while each page contains photos, excerpts and summaries of the content found in $U_{j} I d o k k$, the margins display an easy-to-find publication date, a one-sentence summary of the historical events featured in the news that week, and even poems that had been published at the time. Most importantly, the brief parenthetical references to the topic or field that an article covers (including assimilation, ethnic Serbs in Hungary, Armenians in the Partium region, the new "ideal woman," recipes for wartime soup, middle-class marriage, or imperialism in the Far East, to name just a few of the mentioned topics) makes it incredibly simple for any reader to

\footnotetext{
${ }^{1}$ lo.bello.maya.jean@tok.elte.hu
}

(cc) BY

ULIS D-ferle
New articles in this journal are licensed under a Creative Commons Attribution 4.0 International License.

This journal is published by the University Library System of the University of Pittsburgh as part of its D-Scribe Digital Publishing Program and is cosponsored by the University of Pittsburgh Press 
find his or her most appealing area of interest merely by skimming through the volume's margins. In other words, this format successfully combines the physical advantages contained in a printed volume with the speed inherent in the "keyword search" that readers have become accustomed to in the Digital Age.

Kádár's parenthetical categorization guides the reader through a vast maze of information while unobtrusively supplying a deep understanding of the period, in lieu of which the reader would undoubtedly remain unaware of the socio-historical significance underlying the journalistic or literary works that Kádár has highlighted. Each page therefore offers a microhistorical snapshot of a week in Hungary during World War I, as told from the perspective of the subjects discussed in a family-oriented, general interest weekly that was intent on supporting middle-class ideals at a time when Hungarian society was experiencing the upheaval caused by war, modernization, emancipation and assimilation. By placing her "barely there" commentary in the marginalia, Kádár not only keeps this fascinating narrative firmly in the forefront, but also establishes a dialogue between the past and the present reader, one whose observations subtly place the "current events" unfolding before our eyes within a historical context. The final result is an invitation to browse through a vast field of topics that has been elegantly-yet quite discreetly - been supplied with signposted paths that urge the reader to either forge ahead in the original direction or explore new avenues. Kádár's parenthetical signposting simultaneously fulfills the fundamental role of informing the reader of the methodology and criteria she used while selecting material from $U_{j} I d o ̋ k$, a seemingly inconsequential aspect that guarantees academic integrity while only slightly indicating the countless hours that went into this impressive "archaeological dig" conducted over thousands of pages of material. The combination of original excerpts with content summaries provides a brief taste of the style and language used at the time without overburdening the reader; while I recognize the fact that summarizing lengthy articles enabled the inclusion of far more sources, I wonder whether this technique will inadvertently further the growing habit of reducing academic study to the perusal of abstracts rather than motivating the reader to seek out the original. Although it may seem unimportant, my initial concern that the book's soft — yet sturdy — cover hides the kind of glued binding that often portends a beloved volume's quick dissolution to scattered pages happily proved unfounded: the volume's sewn binding (an expense that many publishers avoid in Hungary) guarantees further ease in reading it, a welcome detail that underscores the OSZK's dedication to producing books that are meant to endure actual usage.

On the title page, Kádár categorizes the volume as a "képes történelmi-kulturális olvasókönyv" [an 'illustrated historical and cultural reader'], a definition that underscores this compilation's ultimate goal of furthering a broader understanding of the historical, sociological, literary and cultural processes that were occurring in Hungary parallel to the mind-shifting changes brought about by the first modern war, World War I. Although Kádár could have chosen any one of the 747 Hungarian-language periodicals that were registered as being in circulation in 1896, two years after the widely recognized author, playwright and politician, Ferenc Herczeg (1863-1954), ascended to the helm of Új Idók (a position he would continue to hold until 1944), her decision to focus on this "liberal-conservative" paper that was closely tied to Hungary's Prime Minister at the time, Count István Tisza (1861-1918), is largely fueled by Kádár's extensive interest in exposing how a periodical influences processes in socialization. As Kádár explains, "Even though the paper reassured its readers of its political objectivity, it still introduced models of social identity that furthered the continuation of traditional political and 
cultural values. Regularly published photographs displayed the ruler and his family in a favorable light; the paper itself never judged the government, instead preferring to issue a light scolding in connection to one matter or another. Herczeg's weekly thereby aided the maintenance of a monarchic state system, a move that also preserved the hegemonic position of a political leadership that consisted of representatives from the middle nobility or aristocratic classes" ['Olvasóit ugyan biztositotta politikaellenességéröl, ám ennek ellenére mégis társadalmi identitásmodelleket mutatott be, s a politikai és kulturális értékek áthagyományozódását segitette. A rendszeresen közreadott fényképeken kedvezö színben tüntette fel az uralkodót és családját, soha nem bírálta, legfeljebb némely esetben szelíden korholta a kormányt, ezáltal Herczeg lapja segitette a monarchikus államberendezkedés fenntartását és a középnemesség és arisztokrácia képviselőiböl álló politikai vezetö réteg hegemon poziciójának megörzését'] (16). In effect, this volume reconstructs the type of periodical formation Andrew Thacker and Peter Brooker refer to in The Oxford Critical and Cultural History of Modernist Magazines (2009) when they state that "To treat literary periodicals as 'formations' is to foreground their own complex social character as the character of the groups that they are traditionally associated with" (Thacker and Brooker, 10), a concept adapted from Raymond Williams's vision of cultural formations described in his Culture and Society: 1780-1950 (New York: Columbia UP, 1968, 70). Given Kádár's extensive (and often pioneering) research into the largely forgotten oeuvres of early twentieth-century female writers, from a more personal standpoint The New Times During World War I foregrounds the socio-cultural and historical context within which authors such as Anna Tutsek, Terka Lux or Cécile Tormay fought to establish careers by writing for "family-oriented" publications like Új Idők.

Although Kádár's monograph of six female authors, Engedelmes lázadók ['Dutiful Rebels'] (2014), briefly reviews topics such as women's rights and the suffrage movement in Hungary, her week-by-week compendium of how women belonging to the middle or ruling class were portrayed, photographed and discussed in $U^{\prime} j I d o k k$ genuinely immerses the reader in the social and cultural milieu that early twentieth-century women writers deeply understood, yet were often compelled to rebel against. Rather than representing a detour from Kádár's main body of research, her journey through Új Idök's wartime years functions as a companion to her previous works in that it thrusts the reader into the somewhat liberal, more often conservative, always paternalistic worldview that was reflected (or rejected) in works by Tutsek and Lux or the more well-known Minka Czóbel, Reneé Erdős, Margit Kaffka and Cécile Tormay. More importantly, recreating these pivotal four years of $U^{\prime} j I d{ }^{\prime} k$ 's publication history exposes the reader to this weekly paper's role in forming and grooming the tastes of its mainly female readership at a time when the mechanisms of political and wartime propaganda were becoming well-oiled in mainstream Hungarian journalism. As such, The New Times During World War I can additionally be viewed as an in-depth continuation of another OSZK publication, ed. by Iván Bertényi Jr. et al., Propaganda - politika, hétköznapi és magas kultúra, müvészet és media a Nagy Háborúban ['Propaganda: Politics, Weekday and High Culture, the Arts and Media During the Great War'] (2016).

To the observer, the hours spent huddled over yellowing newspapers in OSZK's admittedly outdated and thoroughly worn reading room, combing through page after dusty page, are never glamorous ones. Some may even feel that publishing the results of such an effort is esoteric at best, a waste of taxpayers' money at worst. At first glance, The New Times During World War I seems to be nothing more than a practical handbook that can be idly thumbed 
through while hoping that the OSZK's antiquated dumbwaiter system will soon rumble up from the stacks, delivering books requested via handwritten forms filled out in duplicate. Yet, when viewed from the perspective of Judit Kádár's dedication toward recovering the lives and works of Hungarian literature's forgotten female authors, this volume represents a turning point in a lifetime of research: an expanded focus that looks beyond a narrow field to piece together the historical and socio-cultural background that led to the subject's formation. Kádár's recent work reproduces the photos, articles, serial novels and advertisements perused by thousands of Hungarian households, the resources of which were being stretched to the limit by a set of increasingly grave circumstances. By doing so, Kádár not only converts a vast compilation of information into a format that opens the study of this era to a broad array of researchers and curious readers alike, but also demonstrates the need to unearth and piece together the context underlying a system's ability to first influence, then manipulate and ultimately define public opinion. Kádár accomplishes this rare feat by reducing her own role to the margins, where she offers the reader a set of neutral signs that can either be followed or not. Whether this volume will accomplish its goal or not remains unknown. I, for one, am simply grateful to immerse myself in a single treasure from OSZK's immense trove, as I await for the next chapter in this revered institution's history to unfold. 